Matias Kaihovirta*

\title{
Maintaining paternalism, retaining patriarchy: Gender and class in a Finnish industrial company, 1880-1980**
}

\begin{abstract}
This article examines industrial paternalism in Finland throughout a century, from the 1880 s to the 1980 s, and coincides with the rise and decline of industrial society in the history of Western capitalism. The focus of the article is on social relationships between management and employees in an ironworks in Billnäs, located in south-western Finland, and how it developed and changed during the studied time period. Applying a microscopic historical analysis, this article looks at universal phenomenon, namely concerning social relations and gender in the world of industrial paternalism in concrete detail. In addition to a historical understanding of paternalism, the article also contributes to a broader understanding of the relationship between social and economic relations in paternalist organizations with a view to exploring the cultural understandings of gender and class.
\end{abstract}

Keywords: history of industrial paternalism, Finland, class, gender.

(JEL: D22, J16, J59, N83, N84)

\section{Introduction}

Paternalism, Gender and Class in the Age of Modern Industrialization

In a letter to the editor of the Social Democratic newspaper Arbetet in 1917, a worker from Billnäs, an ironworks village in south-western Finland, reported that the management had introduced the "Taylor system", the "scientific management" originally introduced in the US by the American engineer Frederick Winslow Taylor to improve industrial efficiency. Scientific management or Taylorism had already gained a foothold in Northern Europe and especially in Finland after the introduction of F. W. Taylor's scientific management in 1912 in both the bourgeois and the socialist press (Kettunen, 1994, p. 101-104). In the letter, the writer expressed his frustration over Taylorism and the increased competition in the workplace between the workers to the editor, which was not atypical at all among workers. But the writer, who we can for good reason assume belonged to the local metalworkers trade

* Dr. Matias Kaihovirta (corresponding author): University of Helsinki, Political History, PL 54 (Snellmansgatan 14 A), 00014 Helsingfors universitet, Finland. E-Mail: matias.kaihovirta @helsinki.fi.

** Date submitted: October 4, 2019.

Revised version accepted after double-blind review: April 6, 2020. 
union, especially criticized women and young unmarried migrant men who, according to him, pushed down the price for piece wages and thus agreed with the management's attempt to increase the rate of production at the workers' expense. According to the frustrated writer, the management, in their hurry to introduce a Taylorist system, had forgotten about their paternal responsibility to support "working fathers" and their families. ${ }^{1}$

It was not the first nor the last time the unionized workers, representing the married men and family fathers at the ironworks, attacked women and young unmarried working-class men and criticized the management for pushing down wages. Fellow workers who did not represent the male family breadwinner were portrayed as rivals in the local labour market. Innovations made to raise production levels and at the same time to discipline the workforce usually led to conflicts between employers and workers. However, organized workers more or less defended their right to act as family breadwinners and did not condemn innovations such as Taylorism - for them, supporting an unequal social system was paternalism and the patriarchal family model in essence defended working-class livelihood against capitalist exploitation.

\section{Literature Review}

\section{Gender and Class in Industrial Paternalism}

This article examines from a class and gender perspective working-class livelihood and agency in a Finnish paternalistic industrial company during a 100-year period that coincides with the rise and fall of modern industrialism in the industrialized Western world. Gender is a fundamental way of organizing social relations by categorizing men and women into different social roles based on their biological sex in relation to each other and in the relationships and hierarchies that exist in organizations (Scott, 1999; Kessler-Harris, 2007).

In particular, I point to the importance of masculinity in understanding workers' agency and their relation to industrial paternalism. The industrial workers in strong export industry industries have usually been men. However, from a gender perspective it can be seen that the social construction of gender has had an impact on how working-class men in these industries have obtained a strong and privileged position in the working class in comparison with women or other men who also belonged to the working class but within other production sectors with poorer working conditions, wages and benefits. In addition to this, men usually have a better pay and higher wages than women in the same branches and assignments at the work place. This can be understood as the result of the social construction of gender and gender roles. Moreover, men acting as family breadwinners and main providers in the heterosexual family have earned higher wages and family wages.

1 Arbetet, 10 September 1917. 
Other aspects related to the construction of working-class masculinity have included such social and cultural norms related to gender as "respectability", a term related to fatherhood and male paternal responsibilities. These aspects show the importance of gender as a social construction and cannot be ignored when dealing with workers' livelihood and agency in an industrial paternalist system (Rose, 1992).

The industrial company that is the focus of this article was heavily male-dominated and through the studied time period, the explicit understanding of the concept of worker was that it doubtless meant an adult man. The management also consisted entirely of men. Despite this, women were not invisible in the company. Admittedly, there were exceptions with women working at the factory, but above all, women were expected to be housewives in the industrial community built around the company with the task of caring for children and the household while the man of the house worked at the factory. The division of labour was strictly gender segregated here as elsewhere in the industrialized world. In other words, this type of industrial paternalism was patriarchal and was based on centuries of patriarchal power, the accepted norm for male/female relationships in Nordic Lutheran rural society. In other words, the patriarchal household model remained in the modern paternalistic corporate organization and structured the division of labour between men and women in the local industrial community. Despite this, no social organization is static or immune to the changes that are happening in the surrounding society. Social relationships such as paternalism and gender are formed and transformed over time.

This article examines the relationship of paternalism to notions of working-class manhood. My starting point is that modern industrialism enforced new ideals, norms, ideas, expectations and fears associated with working-class men and women. How did they manifest themselves and how did they change during the studied time period? How did notions of gender relate to paternalism and the changes that took place in the surrounding society? To answer my questions, I apply a cultural analytic method that highlights the practices, notions and interpretations used by contemporary historical agents in the industrial community. I particularly focus on the workers' experiences and understandings of paternalism, class and gender (Rose, 1992; Tone, 1997).

The Danish ethnologist Niels Jul Nielsen (2017), who has studied paternalist relations and workers' everyday lives in a Danish industrial workplace, uses the concept of life mode rather than class and class interests when analysing workers' subjective intentions to, for example, support the socialist labour movement:

When workers support the labour movementit is thus, in this approach, understood as an endeavour to improve conditions of reproduction as wage-earner and not as an effort to establish another economic system, where wage-earners in principle have no place. Accordingly, the practise of workers - maintaining internal demarcations - in this approach appears rational and reasoned, even though their struggle never fundamentally challenges capitalism but in practise leads to capitalism's consolidation. (Nielsen, 2017, p. 36-37) 
These practices, as described by Nielsen, can also be interpreted as the intention of workers to support industrial paternalism: "to improve conditions of reproduction as a wage-earner" as a life mode under capitalism. Thereby, workers as wage earners experienced themselves as partners in the industrial paternalist system in order to secure their interests and reproduction in a capitalist system.

\section{Methodology}

The data used for this research consist of both material about and of the workers during the period studied, such as company archives, newspapers, labour movement archive material and workers' memoirs. My research results are presented through the historical narrative, which partly presents the result of my close reading in combination with a theoretical-analytical interpretation of the historical sources. For this article I apply a micro-historical methodology: by a close reading of historical events that took place in Billnäs during the given time period, my aim is to study larger societal phenomena and show how these were shaped by means of concrete historical details (Levi, 1991).

The article studies the historical development at Billnäs ironworks, from the extensive $19^{\text {th }}$-century production conversion to the 1980 s industrial shutdown. Billnäs was founded during the age of the great power period in Sweden in 1641 in the eastern half of the kingdom, in today's south-western Finland. The village and its surroundings, located in the former Pojo municipality was in the early 1900s Finland's most industrialized rural municipality due to the many industrial communities within the municipality. Billnäs ironworks went from rod and pig iron production to becoming one of Finland's leading tool and office furniture manufacturers in the late 1800s. Production was renewed at the ironworks, from craft iron-making to mechanized mass production. From the beginning of the 1900s to the 1980s, the ironworks had just over 300 employees with the exception of the war years (190405, 1914-18, 1939-44), when the number of employees could be twice as much as during peacetime. The industrial production at the ironworks continued until the 1980s, when production decreased and the ironworks were relocated to new facilities, leading to the closure of much of the centuries-old industrial production at Billnäs (Tegengren, 1949; Björkman et al., 1991).

\section{Results}

Making Workers manly? Paternalism Urging Working-class Men to Become Respectable

The growing workforce at Billnäs ironworks meant that the owner, F. L. Hisinger, together with a management consisting of engineers and clerks, had to deal with the contemporary "social" or "labour question". The social and political challenges that followed industrialization threatened misery among the growing number of workers, which in turn was considered to lead to increased political unrest in society. 
The foreign examples, notably the Paris Commune in 1871 but also the strikes that had also reached Finland, triggered, among other things, employers to take preventive measures to counter the spread of socialist ideas among their workers (Kettunen, 2002; Åmark, 2005). Hisinger, like other contemporary industrialists, represented a conservative view of society and was among those who saw themselves as having a paternalistic responsibility for the workers. According to Hisinger, the ironworks community would become a sort of conservative ideal society in miniature, where the patron acted as society's responsible householder who, with paternal care, took care of his subordinate workers, acting as their protector from the dangers of the outside world. ${ }^{2}$

Male workers in particular represented a certain social and political threat to the norms of bourgeois society. The harsh and uncivilized sides of working-class men, with their heavy drinking, violent and erratic behaviour and immaturity, needed to be disciplined by the employer in order to foster a steady and dedicated worker who would adjust to modern industrial work. A steady worker was a guarantee for steady production and industrial peace. Especially working-class men with families were, from the employer's perspective, sought-after employees. Men with families were expected to be bound to their responsibilities as breadwinners. Billnäs founded and funded various types of civic charities, with the goal of improving working families' living conditions at the ironworks. The counter image to the idealized steady, sober, responsible and skilled male worker, was the unruly worker who, in the contemporary paternalist anti-socialist rhetoric, was usually was associated with union activists and agitating troublemakers, eager to ruin the "harmonic" paternalist relationship between the patron and his loyal workers (Kaihovirta, 2015).

Educating workers for a decent life was a matter of order for the paternalistic employer, and sobriety was one of the ideals Hisinger sought among his workers. Male workers were encouraged to lead sober lives, the responsibility for keeping men from grabbing the bottle falling to their wives. Working-class wives were advised to create a comfortable home and instructed in childcare. A pleasant home would keep the husband satisfied, making him spend more time with his family rather than using his spare time in the company of other working-class men. ${ }^{3}$ Male bonding activities were not only, as already mentioned, a social problem that led to the misuse of alcohol and consequent unruly behaviour - they were also considered a political threat. When working-class men gathered together in groups, they might well cause interruptions in the production with strikes and other activities threatening the industrial peace (Kaihovirta, 2015, p. 138-139).

The bourgeois production of knowledge concerning the working class at the turn of the century, in which male workers were seen as politically unreliable and as social

2 Hufundstadsbladet, 20 September 1901.

3 Fiskars Museum archives, Billnäs Temperance Association, handwritten history from the 1910 s. 
problems, led to the exercise of paternalistic control and disciplining the labour force of individual companies. But paternalism was not only challenged by socialists, who saw paternalism as preventing workers' emancipation, liberals and nationalists too were critical of proprietors' conservative paternalism. From the perspective of both liberals and nationalists, it was important that the working class was also included in the modern civil society and the future nation-state. ${ }^{4}$ Paternalism was considered to make working-class men dependent on their employers and prevented men from the lower social classes from being emancipated (Clark, 2007).

Proprietor Hisinger was partially accommodating to his critics and allowed the formation of bourgeois associations in Billnäs that also included workers. After all, Hisinger and his management felt that various leisure activities, especially for workers, were better than joining socialist workers' associations or trade union organizations. The company sponsored the sports association and the voluntary fire brigade at the ironworks, both associations being led by persons representing the company management. The management did not consider that these associations would threaten the paternalistic hierarchy, quite the opposite, they would instead strengthen the communal bond between workers and management. Male workers and men who represented the management would, with the company as a common factor, collaborate together, instilling a feeling that everyone had their given place in the ironworks community, and constructing a sense of male fraternal companionship within the paternalist community. 5

The first socialist workers' associations were founded shortly after the national general strike in November 1905 and the formation of the local metal workers' union in 1907. The labour association which was founded in Billnäs and elsewhere, worked on the principle of making working-class men equal political subjects with bourgeois men, by, among other things, demanding co-determination in municipal politics and safeguarding working-class interests in national politics. The Social Democratic labour association included working-class men as well as women, while the trade union organization had predominately male members. Politically active union workers at the ironworks continued to strive to improve especially the position of working-class fathers by demanding increased wages for men with wives and underage children (Koivisto, 2007, p. 39-44).

Franchise reform in Finland in 1906 was internationally very radical for its time, when both adult women and men were given the opportunity to vote in parliamentary elections. In the first modern Finnish parliamentary elections in 1907, female representatives were also elected. The workers in Billnäs who were in leading positions in the local Social Democratic labour association and trade union organizations were the local "labour aristocracy" of the ironworks. They included skilled

4 Hufundstadsbladet, 30 September 1901.

5 Fiskars Museum archives, Billnäs Voluntary Fire Brigade's archive, The Fire Brigade's 40-year history written in 1938. 
blacksmiths and carpenters at the ironworks who could use their bargaining position to gain social benefits and their share of the profit of the paternalistic system (Kaihovirta, 2015, p. 128-137).

Particularly during times of crisis, when the paternalistic system was under stress, the local labour movement guarded its members' position in the ironworks community. The First World War gave an economic boom to the Finnish metal industry thanks to armament orders from the Russian army, but at the same time the war became a major strain especially for the working classes with the high cost of living and food rationing. As a small open economy, heavily dependent on the conditions in Russia and the outside world, Finland was soon thrown into a serious food crisis when the war entered its third year in 1917.

Demands for fair food distribution were undoubtedly the focus of the masses of workers who revolted in the cities and in the countryside. As Thompson (1991) point out in his use of the concept of moral economy, workers expected that during times of crisis employers would fulfil their part of the contract and take paternal responsibility for their employees. In Billnäs, organized workers demanded that the management would assist the worker's families at the ironworks. One reported injustice was that the management did not intervene in alleged food speculation, favouring black market trade in the municipality, and no distinction was made between workers with families and those who either profited from the food trade for their own gain or temporary workers without maintenance. In trade union organizations the employer was condemned for hiring "outsiders" and women rather than raising the wages of local fathers. The local Social Democratic labour association also condemned younger male workers without family and temporary workers at the ironworks for their unruly behaviour, staining the good reputation of the more respectable organized workers, who were now eager to step in and take charge of business on the local political level in the municipality (Kaihovirta, 2015, p. 254266).

Shortly after the Finnish Declaration of Independence in December 1917, a Civil War broke out between "Red" socialists and the "White" bourgeoisie. Billnäs was located in Red-controlled Finland and a Red Guard was also established at the ironworks, and the majority of the workers enrolled into it. Most of the Reds in Billnäs were fathers. Although a socialist revolution was declared in the country, work at the ironworks continued without interruption and the management as well as the proprietor Hisinger was left alone by the local Reds. The Reds at the ironworks saw it as their task to maintain order in the local community and ensure that the scarce food storages were not plundered by outsiders. In principle, it can be said that the Reds in Billnäs tried to restore the paternalistic social system that existed before the troubled times that supported stable workers with families. The change of power, when the management regained control of the ironworks in April 1918, took place 
with the help of the German intervention in the Finnish Civil War and which led to the capitulation of the Reds in May 1918 (Kaihovirta, 2015, p. 268-274).

\section{Defending and Contesting Paternalist Pale Respectability 1918-1939}

In Billnäs the management, which identified itself with the White victors of the Civil War, undertook the task of restoring order at the ironworks after the workers' uprising, preventing a new uprising from occurring and, above all, restarting production at the ironworks and thus returning things to 'normal'. Industrial peace was strongly related to the Finnish bourgeois task of defending the legacy of the White victory in the Civil War. The White victory was seen as the fulfilled liberation of Finland from the yoke of Russian Bolshevism (Kettunen, 2002, p. 282-283, 294296).

In reality very few of those who had participated on the losing side of the Civil War were devoted Bolsheviks or even socialist revolutionaries. These circumstances were recognized by White employers, but the narrative of Bolshevik agitators infiltrating the 'harmonious' community, and misleading the steady ironworkers into joining the Red Guard against their own free will, suited well with the paternalist rhetoric. ${ }^{6}$

However, the management was eager to restart the production at the ironworks as soon as possible after the war. Shortly after the Civil War the demand for skilled workers was naturally high. The labour supply was severely limited, however, due to the fact that some 80,000 Finns who were on the Red side during the war were in prison camps. The White bourgeois government recognized that the problem with the Red prisoners had to be quickly resolved, especially when the conditions at the prison camps were very poor and mortality was high during the summer of 1918 . The government established state criminal courts to try the Red prisoners, and the vast majority of the prisoners were released during the summer and early autumn of 1918 (Tikka, 2018, p. 102-108).

The legal proceedings that began in the summer of 1918 against Red sympathizers were very extensive and to a large extent unjust. The then Finnish judicial system could in no way be considered to comply with the principles of justice when the plaintiffs, prosecutors and judges at the trials all belonged to the same side. In order to facilitate the legal process, the courts asked for statements about the accused from their former employers (Kekkonen, 1991, p. 35-38, 48-67, 73-90). Employers were thereby given the opportunity to influence future labour market conditions by sifting out "troublemakers", mainly trade union activists, and giving them "the hardest possible punishment". In some cases this meant the death penalty or serving a life-long prison sentence, while on the other hnd skilled and steady workers were taken back to restart production, though of course subject to the employer's control (Tikka, 2004, p. 331; Kaihovirta, 2018, p. 122-124). 
The management in Billnäs began putting up lists of names of workers who were believed to have been "misled" by the Red Guard and who "against their will" and "better judgement" had joined the Reds during the war. The company were willing to take these workers back, and as was often pointed out in the letters written to the state criminal court by the management, the men were needed as "skilled workers" to restart production and "for the sake of the numerous families involved". 7

Steady and reliable workers became even more linked to the employers' political and social responsibility to society as a whole and to preserve the White social peace at the local level. Billnäs Bruk Ltd. joined the Finnish metal industry employers' union in the autumn of 1918 , which during the interwar period consistently invested in resources to counteract the "Red" trade union movement. The management tried to control the labour force by "blacklisting" workers who joined the re-born trade unions and socialist labour associations after the Civil War. ${ }^{8}$

However, the repressive measures to maintain order and industrial peace were found to be ineffective, as it was considered counterproductive to create new conflicts between management and workers. A far more effective way, according to the employer, was to strengthen the paternalistic social benefits, especially for the breadwinning male workers with family responsibilities. Wives to the male workers became the source of effective information and support as family mothers and housewives. Through the already existing bourgeois and newly founded philanthropic associations, the company offered financial and material support for the workers and their families. The company employed a counsel system for mothers, paid dental care, arranged school lunches and health examinations for the school pupils at the ironworks, and organized lectures on current topics for the adults and leisure activities for families. ${ }^{9}$

Investment in families and family-related activities became increasingly important as leisure time was increased for the workers after the introduction of an eight-hour working day in Finland in 1917 (though in practice an eight-hour working day was not introduced until some years later in Finnish industry). The employer feared that with more leisure time the workers could devote their time to political and union activity, which would in turn thwart the peace of work. At the same time, there was a tradition at the ironworks to invest in future workers by offering the sons of steady and skilled workers employment at the ironworks. After 1918, there was a clear will on the part of the White management to allow the sons of "misled" Red workers to work in the ironworks, including them in the voluntary fire

7 National Archives of Finland, State Criminal Court Acts, VRO 6248.

8 ELKA, Billnäs Bruk Ltd. Archives, Letter to the Finnish Metal Industry Employer's Union 25 July 1927.

9 Fiskars Museum archives, General Mannerheim's children's foundation branch in Billnäs, Annual reports 1924 \& 1925; Hufvudstadsbladet, 2 June \& 15 September 1918. 
brigade, and in various ways integrating them into the White ironworks community (Kaihovirta, 2015, p. 372-377).

The trade union organizations inherited the fraternalism from the pre-Civil War era and were increasingly reluctant to challenge and disclaim the power of the employer with a vision of proletarian masculinity that the trade union organizations had adopted from the international Communist movement with its base in Soviet Russia. In the trade union, workers were urged to resist the employer's invitations and it was warned that traitors to the working class would be punished. Union leadership demanded of its members that they should resist and stand up "as one man" against the White employer who "slaughtered our comrades" in 1918 and who "now want to suck the life force out of our workers' bodies". Strikebreakers and unorganized workers were feminized and called "weak" and "traitors", "hiding at home" instead of "joining the great army of proletarian working men in their international fight against dehumanizing capitalism". ${ }^{10}$

In the same way as the Communists in the metal workers' union in the 1920s, the Social Democrats in the reformed workers' association were willing to challenge the White paternalistic management and its power in the local community. The Social Democratic labour association in Billnäs was, however, willing to work within the bourgeois society's framework and accepted compromises, engaging in dialogue with the bourgeois about the redistribution of society's resources. Within the labour association, a more reformist-oriented masculinity norm was developed: workers were to be trained in self-discipline and to appear respectable in the eyes of the bourgeois, a reliable and equal citizen of society. Self-education was therefore an important ideal that they sought to fulfil in the labour association (Kaihovirta, 2012, p. 86-91).

At the same time, the patriarchal family model was not questioned: men emerged as a political subject in social democracy, while women represented housewives and did 'traditionally' female chores in the association and society at large. In principle, the Social Democrats did not challenge the social benefits of paternalism directed at steady fathers, but were willing to negotiate with the employer to improve and strengthen the paternalistic model in which workers and their families were offered social security by working for the ironworks company.

\section{Patriarchal Co-option in the Age of the Developing Welfare State from the 1940 s to the 1980s}

During World War II, Billnäs once again became part of the war industry. The Second World War differed from previous experiences of industrial work during wartime, as Finland's war against the Soviet Union (the Winter War 1939-40 and

10 TYARK, Billnäs Industrial Council no. 76's archive, handwritten paper “The Spark - a paper for the union activists in Karis-Billnäs 1927.” 
the Continuation War 1941-44) was depicted in the propaganda as a national sacrifice, where the entire society's resources would be stretched to the utmost to meet the threat to the country's freedom and independence. The Fiskars Group, with its strong metal industries such as Billnäs, became one of Finland's most important manufacturers of grenades and other war materials for the Finnish army. When the Winter War broke out, the obligation to work was imposed on men and women who were not called to do military service and this duty was valid until autumn 1944, when the war against the Soviet Union ended (Tegengren, 1949; Carlson, 1999, p. 148-151).

The Fiskars Group had had some of its male workforce called out to do military service and had lost some of those who had fallen or been severely wounded during the war. However, the new recruitment of labour was not so great as a significant proportion of workers had not been called up and the veterans at the front were able to return to their former workplaces after the war (Carlson, 1999, p. 156161).

The trade union movement became an institutionalized part of Finnish industry during the war. Union employee representatives, an institution introduced in Billnäs in 1944, and trade union representatives negotiated working conditions, wages and other social issues pertaining to workers at the ironworks. A new institution, production committees, which would strengthen cooperation between the management and the employees in the industry, were legislated in 1945 on the initiative of the Communists and the national trade union. The idea was imported from the UK, where production committees had been introduced in wartime industries. From the perspective of the labour movement, efforts were made to strengthen the workers' ability to influence their workplaces, while the employers initially feared that the production committees were the beginning of the Communists' attempt to nationalize private companies. However, the production committees acted only as advisory bodies without executive decision-making rights in the companies. Yet at the local level, workers and the management considered production committees to be a good forum to conduct a dialogue in which both parties had the opportunity to express their views on various issues relating to work, social issues and leisuretime activities. The production committee as an institution existed until 1978 and was then replaced by the present institution of cooperative negotiating in companies (Ahvenisto, 2008, p. 452-462, 469-472).

The negotiating culture that was institutionalized in the industrial workplaces undoubtedly brought the workers closer to the company and increased the workers' understanding of the company's finances and production. The employee representatives would become aware of the 'necessities' that the management must implement with regard to the company's overall interests, and thus ended up in the role of conveying the management's views to the employees. The production committee became a forum where the workers elected their representatives, who in turn were giv- 
en the opportunity to make improvement proposals to increase production, which was extremely welcome for the management, even though all proposals were not approved by the company management.

Simultaneously, the relations on the Finnish labour market were not quite as harmonious and understanding as stated previously. During the late 1940s and early 1950s, fierce and sometimes violent confrontations took place between workers and employers, but also within the labour movement between Social Democrats and Communists. The confrontations were sometimes very bitter and mirrored the international tensions of the Cold War era, but old antagonisms from the days of the Civil War in 1918 and the interwar era also had an impact on the relationship between employers and workers. Like during the interwar era, employers recalled the help of earlier paternalistic rhetoric to maintain industrial peace, by referring to the need for cohesion and also attempting to invoke the famed "Winter War spirit" when employers and workers under threat from the outside worked together in harmony for the common good of the nation. Again during the first Cold War decades, the interest of employers and industrial paternalism was linked to a larger national task, namely, how industry could work for Finland's survival in the Cold War. Other anti-Communists, such as the Social Democrats, would join this view. It was not uncommon for Social Democratic trade union activists to act as strikebreakers in labour conflicts started by Communists (Holmila \& Mikkonen, 2015).

The confrontations on the labour market and in society were reflected in the conditions in Billnäs. The union organization felt that the management had failed to fulfil its duties of both leading the company and bearing responsibility for the social conditions of the workers. In 1948, generally known as a very turbulent year in Finnish political history with the threat of an imminent Communist coup similar to the one in Czechoslovakia, the union organizations in Billnäs demanded that the management resign due to the lack of managerial skills (Koivisto, 2007, p. 126127). Sit-down strikes were organized in Billnäs between the late 1940s and early 1950s. This was a response to the poor social conditions after the war experienced by the workers due to low wages, inflation and rationing. ${ }^{11}$ Another dispute that led to work stoppage was the union organizations demand for increased pensions for the workers who had retired. The management, however, countered this demand by allowing retired workers to stay in the company's housing at the same time receiving free electricity and firewood. The local union organization was very alert to taking up their elderly retired members interests on the agenda in the 1950s and 1960s, as many of the elderly were the pioneers of organizing unions in Billnäs in the early 1900s and also some of them were former Red Guards in 1918 (Koivisto, 2007, p. $138,147-148,153-156)$.

During the war, the number of female employees had increased at the ironworks and the union organization also gained an increasing number of female members 
and there were even women on the union organization's executive committee. The union organization did indeed strive to improve women's working conditions with demands for increased wages for women, improved social conditions for women in the workplace, as well as better workers' protection for female labour. The starting point was, however, not to reinforce gender equality between male and female workers. Women's work was still regarded as a consequence of the fact that women had to work in men's place as a family provider and head breadwinner if the male head of the house had died during the war. This was the case both in 1918 and even later during the Second World War (Koivisto, 2007, p. 138; Kaihovirta, 2015, p. 326-336). In Finland female industrial work in the 1940s and 1950s was regarded as a necessity, but overall it was thought that in the future women in modern society should not have to perform wage work (Suoranta, 2009). By contrast, the workers' representatives, all of them men with families, on the production committee were critical to the recruitment of women after the war and demanded that young men "who had the future ahead" should be given preference in hiring new workers for the ironworks. ${ }^{12}$

Up until the 1960s and possibly even later, there was a consensus among the organized male workers at the ironworks that it was the union organizations' duty to defend the rights of the family men who worked at the ironworks. This was expressed in defence of the paternalistic social benefits given to male breadwinners in the company. An illustrative example was the demand for low-cost owner-occupied houses, especially for male workers who were also war veterans. The company agreed to support home building on a larger scale by assigning rental plots to the company's workers. The workers' representatives in the production committee also negotiated with the management of new housing for young unmarried male workers without families. These new apartment houses had a handicraft room in the basement in order, according to the management, to give young men stimulating spare-time activities instead of "dubious" pastimes. Like before, the voluntary fire brigade and company sports were also considered excellent spare-time activities for male workers at the ironworks, the company and the union organizations both providing financial support to them. ${ }^{13}$

In the 1960s and 1970s, when the Finnish welfare state expanded and the public sector became more extensive, industry relinquished many of the former paternalistic social benefits that employees had received. This included, in particular, the benefits that were aimed at families, such as health care, school, day-care for children, libraries and leisure activities. These were taken over by the municipality or by NGOs that received state grants for their activities. Sickness benefits, pensions and funeral funds provided by industry were disbanded in the early 1960s and new statutory social insurances were introduced linked to the employment relationship

12 Fiskars Group archive, Billnäs Bruks' archive, Production committees, Protocols 1946-1974.

13 Fiskars Group archive, Billnäs Bruks' archive, Production committees, Protocols 1946-1974. 
(Björkman et al., 1991). However, historians studying the construction of the Nordic welfare state have pointed out that the female-dominated public sector both released women to participate in wage work and created job opportunities for women in the public sector (e.g. primary schools, day-care) (Kettunen, 2006, p. 307). However, this model was very similar to the gendered division of labour that was already in operation in patriarchal ironworks communities, with married men working in the "productive" industry and married women in the "reproductive" households and homes of the wage workers.

The workers' demands for increased control over production meant that they were at the same time given greater responsibility for ongoing production that guaranteed that the company was profitable, which in turn was the basic prerequisite for the workers' social welfare. Employee representatives elected by the workers were given greater transparency by the management concerning workplace conditions, but at the same time they had greater responsibility in the workplace for workers doing their job and fulfilling their tasks. In other words, the paternalistic control of the workers was delegated from the management to the employee representatives.

The job of employee representative was not always sought after. In interviews with employee representatives within the Fiskars Group and in a diary written by an employee representative at Åminnefors steelworks, situated only 3 kilometres from Billnäs, the burdensome side of taking social responsibility for one's work colleagues appears when remembering the conditions in the post-war workplace. Alcohol abuse at work and during the workers' leisure time was a recurring problem. Employee representatives were also sometimes expected to resolve family disputes and assist in seeking support for families from the municipality's social council when the father in the family was temporarily incapacitated due to alcoholism. The union organization also saw it as its task to intervene in the "social behaviour" of members or employees and reprimand those who were unable to do their work due to alcohol abuse or other causes. ${ }^{14}$

The metal and steel industry in south-western Finland showed signs of becoming less financially profitable for the owners during the 1960s. Above all, the reduced profitability was due to intensifying international competition in the metal industry market and the Fiskars Group's ironworks in Pojo, despite significant technological innovations in production, had become a loss maker. At the same time, the Group's management had made a number of large investments in business acquisitions that proved to be very costly and lossmaking for Fiskars. The Group hired outside consultants, who began a major restructuring of the business. A decision that would have a significant impact on the local community was the sale of the metal industry and its gradual closure beginning in the late 1960s. The Fiskars Group went on to

14 SLS Archives, 1965 Åminnefors - ett industrisamhälle i förändring, Interview with S. Lindroos; Fiskars Museum's archive, Alfons Flemmich diaries, 21 February 1955; 3 August 1956; 17 November 1956; 20 November 1961; 7 April 1966. 
focus primarily on tool manufacturing, including scissors, which was the company's most successful export product. A new factory for tool manufacturing was inaugurated in 1973 in Billnäs just over a kilometre from the old ironworks, which is still operating today (2020) (Carlson, 1999, p. 172-195; Koivisto, 2007, p. 193-196).

The first major shock to the workers was the closure of the furniture factory in Billnäs in 1971. At that point, it was clear that other production at the ironworks was also threatened with closure. When the ironworks in Billnäs were discontinued in the late 1970s, the union protested when the company withdrew the last traditional social benefits the company had for its employees, i.e. firewood and the laundry and bathhouse sauna. The union organization also protested with sit-down strikes when the first notice of large dismissals came to the knowledge of workers. The worker's expressed their anger when the Fiskars Group bought cheaper materials from abroad for the production of tools instead of those manufactured in Billnäs. The management responded by striving to terminate workers who were approaching retirement age and to relocate others to new tasks within the group (Koivisto, 2007, p. 194-196). The year before the ironworks were completely shut down, a union activist wrote a pamphlet entitled "Dark Clouds over Billnäs", where company management was blamed for deliberately sabotaging production by purchasing raw materials from competitors and where the writer urged workers to review the production themselves to show that the ironworks could still prove economically viable. ${ }^{15}$ Despite some active workers' attempts to persuade the management that the ironworks were not as unprofitable as the consultants hired to carry out business remediation had alleged, the ironworks were shut down in 1984.

Like elsewhere in Finland, the Fiskars Group strove to improve the local collaboration between management and employees in order to implement the necessary renewals and changes for production profitability. In retrospect, this meant that the company management pushed through the closure using traditional paternalistic management methods, the management explaining to workers that industrial shutdown was a good thing for employees as well. At the same time, the management offered workers who could adapt to the new rationalization measures relocation in a new job within the group - that is, according to practices used in the past. Hence, those who were regarded as steady and skilled workers who could adapt to the changes that were sweeping through the industry could orientate themselves in the new industrial production (Koivisto, 2007, p. 193-201). The adaptation to the 'new' industrial production of the 1980s was that industrial companies no longer served only national interest but competed in a global market, where quality and knowledge constituted resources that were considered to make the companies competitive. In this respect, the Fiskars Group has created a brand based on its company

15 TYARK, Billnäs Metalworker's union organization archive, Unpublished article "Dark clouds over Billnäs" (1983). 
history, with a centuries-old tradition of know-how in tool manufacturing for innovative use (Carlson, 1999, p. 206-213).

\section{Conclusion}

In this article, I have studied industrial paternalism in a Finnish ironworks community in Billnäs, a time span of 100 years from the production being restructured and modernized in the late 1800 s to the closure of the industrial production at the ironworks in the 1980s. The article studies how gender and class were intertwined with industrial paternalism. The historical narrative shows how ideas on gender and class, closely connected to working-class livelihood, affected politics within the industrial paternalist system. The article also shows how norms and cultural belief systems that surround the social construction of gender and class, which in turn affects social positions, roles and social relations in industrial paternalism, are the very foundation of economic and industrial relations. To put it simply: economic and industrial relations are not some abstract natural law, they are culturally constructed and imbedded in the webs of human social relations.

The focus of this article has been on the social relations between management and workers, where the concept of paternalism has been used to study the mutual exchange of services and loyalties between the parties in the ironworks community. The workforce at the ironworks was male-dominated, and the article studies how the management deliberately invested in strengthening a patriarchal gender system at the ironworks, fathers of families being considered steady and reliable workers, and from the employer's perspective a guarantee of industrial peace. However, there were also strong gendered hierarchies between men in the paternalist system. Men were categorized according to a heteronormative matrix, where men without wives or families were lower in the social hierarchy or even excluded from the social benefits of the paternalist system and the paternalist community. During the studied time period, the male-dominated trade union organizations in Billnäs were increasingly interrelated to the paternalist system. This shows how paternalism and patriarchalism were not separated from each other, instead they were connected and part of the same gendered social and economic system. This shows how workers' gendered practices, namely the notions that working-class men's manliness meant being able to act as a responsible breadwinner for one's family and being head of a household with a wife and children, strengthened the industrial paternalist system from below throughout the studied time period.

Whether the conversion of industrial production in Billnäs to the present-day scissors and tools factory has created new paternalistic and patriarchal relationships between management and employees, and how this might form a basis for workers' union and political activities today, falls outside this article' scope. However, this 
would be worth investigating in future research and without doubt "history matters" for such a study as well.

\section{Acknowledgements}

This work was supported by Society of Swedish Literature in Finland.

\section{References}

Ahvenisto, I. (2008). Tehdas yhdistää ja erottaa Verlassa 1880-luvulta 1960-luvulle. Helsinki: SKS.

Åmark, K. (2005). Hundra år av välfärdspolitik. Välfärdsstatens framväxt i Norge och Sverige. Umeå: Boréa.

Björkman, S., Heporauta, A. \& Tuomi, T. (1991). Billnäs: fem årtionden av industri- och sambällshistoria. Pojo.

Carlson, C. E. (1999). Fiskars 350. Helsingfors: Otava.

Clark, A. (2007). The rhetoric of masculine citizenship: Concepts and representations in modern western political culture. In: S. Dudink, K. Hagemann \& A. Clark (eds.), Representing Masculinity: Male Citizenship in Modern Western Culture (pp. 3-22). Oxford (UK): Palgrave Macmillan.

Holmila, A. \& Mikkonen, S. (2015). Suomi sodan jälkeen: pelon, katkeruuden ja toivon vuodet 1944-1949. Jyväskylä: Atena.

Kaihovirta, M. (2012). Skjutövningar och pennfäktning. Manliga medborgarideal och politisk verksamhet i Billnäs brukssamhälle, ca 1918-1930. Historisk Tidskrift för Finland, 2012:1, 73-94.

Kaihovirta, M. (2015). Oroliga inför framtiden. En studie av folkligt politiskt agerande bland bruksarbetarna i Billnäs c:a 1900-1920. Helsingfors: THPTS.

Kekkonen, J. (1991). Laillisuuden haaksirikko. Rikosoikeudenkäyttö Suomessa vuonna 1918. Helsinki: Lakimiesliiton kustannus.

Kessler-Harris, A. (2007). Gendering Labor History. Chicago: University of Illinois Press.

Kettunen, P. (1994). Suojelu, suoritus, subjekti. Työsuojelu teollistuvan Suomen ybteiskunnallisissa ajattelu- ja toimintatavoissa. Helsinki: SHS.

Kettunen, P. (2002). Från arbetarfrågan till personalpolitik. In: A. Kuusterä (ed.), Ett storföretag och dess omvandling. Parteks hundraariga historia (pp. 265-384). Helsingfors.

Kettunen, P. (2006). The tensions between the social and the economic - A historical perspective on a welfare state. In: J. Ojala, J. Eloranta \& J. Jalava (eds.). The Road to Prosperit: An Economic History of Finland (pp. 285-313). Helsinki: SKS.

Koivisto, J. (2007). Verktygsarbetarnas hundraåriga fackliga verksamhet i Billnäs brukssamhälle. Billnäs metallfackavdelning nr 21 1907-2007. Helsingfors.

Levi, G. (1991). On Microhistory. In: P. Burke (ed.). New Perspectives on Historical Writing (pp. 93-113). Cambridge (UK): Polity Press.

Nielsen, N. J. (2017). The worker between practise and ideology from the 19th to the 21st century. Revista Murciana Antropologia, (24).

Rose, S. O. (1992). Limited Livelihoods: Gender and Class in Nineteenth-century England. Berkeley: University of California Press. 
Scott, J. W. (1999). Gender and the Politics of History. A Revised Edition. New York: Columbia University Press.

Suoranta, A. (2009). Halvennettu työ: pätkätyö ja sukupuoli sopmimusyhteiskuntaa edeltävässä työmarkkinakäytännöissä. Tampere: Vastapaino.

Tegengren, H. (1949). Billnäs Bruks historia. Minnesskrift på uppdrag av styrelsen för O.Y. Billnäs A.B. Helsingfors.

Thompson, E. P. (1991). Customs in Common. New York: The New Press. 